\title{
Formulasi paduan karet alam/kloroprena dalam rancangan material komposit karet untuk bantalan isolator tahan gempa
}

\section{Formulation of natural/chloroprene rubber mixture in designing rubber composite material for seismic isolator bearing pad}

\author{
Adi Cifriadii ${ }^{*}$, Santi Puspitasari ${ }^{1}$, Asron Ferdian Falaah ${ }^{1}$, Usman Wijaya $^{2}$ \\ ${ }^{1}$ Balai Penelitian Teknologi Karet - Pusat Penelitian Karet, Jalan Salak Nomor 1, Bogor 16128, Indonesia \\ ${ }^{2}$ Universitas Kristen Krida Wacana, Jalan Tanjung Duren Raya No 4, Jakarta Barat, Indonesia \\ *Penulis korespondensi. Telp. +62 $2518317819 / 8324047$ \\ E-mail : cifriadi9748@gmail.com
}

Diterima: 06 April 2021

Direvisi: 26 November 2021

Disetujui: 28 November 2021

\section{ABSTRACT}

The usage of base isolator system on a building construction can mitigate damage during earthquake. The most common base isolator system is seismic rubber bearing which composed of alternating rubber composite layer and steel plate layer. Rubber composite is produced from natural rubber (NR), chloroprene rubber (CR), and its blend $(C R / N R)$. The experimental research aimed to study the effect of $C R / N R$ ratio on rubber composite through rubber compound formulation design. Rubber compound formula were designed by varying the CR/NR ratio as $95 / 5 \mathrm{phr}$, 90/10 phr, 85/15 phr, and 80/20 phr. Combination of efficient sulfur curing and metal oxide curing were applied to the system. The result of curing characteristic analysis and mechanicallthermal properties test showed that blend of CR/NR as 90/10 phr was the most optimum ratio. This composite of rubber blends was highly potential to be developed as seismic rubber bearing (HDRB shear modulus 1.1 - 1.5 MPa) since it has better processability (ML as $1.17 \mathrm{~kg}-\mathrm{cm})$, high crosslink density (MH-ML as $12.58 \mathrm{~kg}-\mathrm{cm})$ followed with excellent mechanical and thermal properties which was illustrated with good retention on tensile strength (2.4\%) and elongation at breaks (-2.4\%).

Keywords: base isolator, chloroprene, natural rubber, seismic rubber bearing.

\section{ABSTRAK}

Penggunaan sistem isolasi dasar pada suatu konstruksi bangunan dapat memitigasi kerusakan pada saat terjadinya gempa bumi. Sistem isolasi dasar yang paling umum digunakan adalah karet tahan gempa yang tersusun oleh lapisan komposit karet dan pelat logam secara berselang seling. Komposit karet dapat dibuat dari karet alam (NR), karet sintetik (kloroprena), dan paduannya (CR/NR). Riset eksperimental ini bertujuan untuk mempelajari rasio CR/NR pada paduan komposit karet tahan gempa melalui proses desain formulasi kompon karet. Formula kompon karet dirancang dengan memvariasikan rasio CR/NR sebesar 95/5 phr, 90/10 phr, 85/15 phr, dan 80/20 phr. Sistem vulkanisasi dirancang dengan menerapkan kombinasi sistem vulkanisasi sulfur effisien dan oksida logam. Hasil analisis karakteristik vulkanisasi dan pengujian sifat mekanik serta termal komposit paduan karet CR/NR menunjukkan bahwa komposit paduan karet CR/NR sebesar 90/10 phr merupakan komposisi paduan karet yang terbaik. Paduan karet tersebut berpotensi untuk dikembangkan menjadi produk karet tahan gempa jenis HDRB (modulus geser 1,1-1,5 MPa) karena dapat menghasilkan kompon yang mudah diproses (ML 1,17 kg-cm), derajat ikatan silang yang tinggi (MH-ML 12,58 kg-cm) dan diikuti dengan sifat mekanik dan termal yang unggul dibuktikan dengan perubahan nilai kuat tarik $(2,4 \%)$ dan perpanjangan putus $(-2,4 \%)$ setelah pengusangan yang terrendah dibandingkan dengan komposisi CR/NR yang lain.

Kata kunci: karet alam, karet tahan gempa, kloroprena, sistem isolasi dasar.

\section{PENDAHULUAN}

Sistem isolasi dasar merupakan suatu sistem yang difungsikan untuk memitigasi dampak gempa bumi pada suatu konstruksi bangunan baik gedung maupun jembatan dan jalan layang (Ramallo et al., 2002). Pemasangan sistem isolasi 
dasar yang dilakukan diantara bagian pondasi atau tanah (ground) dan bagian bangunan (upper structure) diketahui dapat menyerap getaran yang ditimbulkan oleh gempa bumi sehingga dapat mengurangi aliran energi yang diterima oleh bangunan tersebut pada saat terjadinya gempa bumi (Verma et al., 2017). Oleh karena itu syarat utama suatu material dapat digunakan sebagai pembentuk sistem isolasi dasar adalah memiliki sifat mekanik, termal, dan redaman yang baik. Sifat termal terutama ketahanan ozon dan oksigen yang unggul diperlukan agar sistem isolasi dasar yang diaplikasikan di luar ruangan tersebut mampu menangkal serangan oksigen dan ozon pada jangka waktu lama sehingga memiliki umur pakai panjang.

Menurut Warn dan Ryan (2012), sistem isolasi dasar dapat diklasifikasikan menjadi dua kategori yaitu elastomerik dan sliding. Tipe elastomerik yang terdiri atas material komposit karet dan pelat logam yang tersusun secara berselang seling juga dikenal dengan istilah "karet tahan gempa (seismic rubber bearing). Sedangkan tipe sliding menggunakan material polytetraftuorethylene dan baja tahan karat. Tipe elastomerik yang paling banyak dikomersialkan adalah jenis lead rubber bearing (LRB) dan high damping rubber bearing (HDRB). Sementara tipe sliding yang banyak ditemukan adalah jenis friction pendulum bearings (Ferraioli \& Mandara, 2016). EN 15129 tentang Anti Seismic Devices mengatur kategori kinerja karet tahan gempa berdasarkan kisaran nilai modulus geser menjadi I (0,3-0,7 MPa), II $(0,7-1,1 \mathrm{MPa})$, dan III (1,1-1,5 MPa). Modulus geser yang terkait dengan kemampuan pergeseran (shear displacement) dari suatu karet tahan gempa ketika terkena getaran gempa menjadi salah satu tolak ukur penting bagi perekayasa dalam memilih jenis karet tahan gempa yang akan dipasang pada suatu struktur konstruksi di lokasi tertentu (Nishi et al., 2019).

Lebih lanjut, sebagaimana juga disebutkan dalam EN 15129, karet yang dapat digunakan sebagai base elastomer dalam pembuatan karet tahan gempa adalah karet alam (NR) dan karet kloroprena (CR). Karet alam memiliki keunggulan dalam sifat mekanik utamanya elastisitas, pantulan, ketahanan abrasi, namun sangat rentan terhadap serangan oksigen dan ozon (Galiani et al., 2013). Pada umumnya polimer dengan kandungan ikatan tak jenuh $(\mathrm{C}=\mathrm{C})$ tinggi yang terus terpapar oleh oksigen dan ozon akan mengalami pengusangan dan timbul retakan di permukaannya sehingga akan berpengaruh terhadap performanya (Olejnik et al., 2019). Sementara karet kloroprena yang memiliki struktur rantai polar (ikatan $\mathrm{C}-\mathrm{Cl}$ ) menyebabkan karet sintetik tipe ini tahan terhadap minyak, paparan oksigen, ozon, dan bahkan api (flame). Struktur rantai makromolekul karet kloroprena banyak menggandung gugus trans 1,4, akibatnya sifat elastisitasnya menjadi rendah (SmejdaKrzewicka et al., 2019). Saat ini pembuatan karet tahan gempa komersial menggunakan karet alam saja atau hanya karet kloroprena sebagai matriks dalam susunan komposit karet. Penelitian ini dimaksudkan untuk mempelajari potensi paduan kloroprena dan karet alam (CR/NR) dalam pembuatan material komposit karet yang sesuai digunakan untuk aplikasi karet tahan gempa melalui proses formulasi kompon karet.

\section{BAHAN DAN METODE \\ Bahan Penelitian}

Bahan penelitian terdiri atas karet dan bahan kimia karet. Karet yang digunakan dalam riset meliputi karet alam tipe Ribbed Smoke Sheet (RSS) Grade Cutting Sheet yang diperoleh dari Koperasi Karyawan INIRO Bogor dan karet sintetik tipe kloroprena yang diproduksi oleh Lanxess dan diperoleh dari Distributor PT Multi Citra Chemindo Nusa Jakarta. Selanjutnya bahan kimia karet mencangkup $\mathrm{ZnO}$ (Lanxess), asam stearat (Rhein Chemie), lilin paraffin (Rhein Chemie), 6PPD (Signorgchem), TMQ (Lanxess), carbon black $\mathrm{N} 220$ (OCI), minyak aromatik (PT Pertamina), TMTD (Shandong), Sulfur (Miwon), dan $\mathrm{MgO}$. Seluruh bahan kimia karet diperoleh dari PT Multi Citra Chemindo Nusa Jakarta, kecuali minyak aromatik yang disediakan oleh Koperasi Karyawan INIRO Bogor dan $\mathrm{MgO}$ yang dibeli dari UD Indrasari. Disain susunan formulasi kompon karet paduan CR/NR disajikan pada Tabel 1.

\section{Peralatan Penelitian}

Pembuatan kompon karet menggunakan mesin giling terbuka skala laboratorium berkapasitas $1 \mathrm{~kg}$ kompon/batch. Selanjutnya pencetakan kompon menjadi vulkanisat dilakukan menggunakan mesin cetak hidraulik.

\section{Metode Penelitian}

Dalam percobaan ini, komposit paduan karet CR/NR yang selanjutnya disebut dengan kompon 
Tabel 1. Susunan formulasi kompon karet paduan CR/NR.

\begin{tabular}{clcccc}
\hline No & \multicolumn{1}{c}{ Bahan } & \multicolumn{4}{c}{ Komposisi paduan karet CR-NR (phr) } \\
\hline 1 & Karet kloroprena (CR) & 95 & 90 & 85 & 80 \\
2 & Karet alam (NR) & 5 & 10 & 15 & 20 \\
3 & ZnO & 5 & 5 & 5 & 5 \\
4 & Asam stearat & 2 & 2 & 2 & 2 \\
5 & Lilin paraffin & 2 & 2 & 2 & 2 \\
6 & 6PD & 4 & 4 & 4 & 4 \\
7 & TMQ & 1 & 1 & 1 & 1 \\
8 & Carbon black N-220 & 50 & 50 & 50 & 50 \\
9 & Minyak aromatik & 20 & 20 & 20 & 20 \\
10 & Etilen tiourea (ETU) & 2 & 2 & 2 & 2 \\
11 & TMTD & 1 & 1 & 1 & 1 \\
12 & MgO & 5 & 5 & 5 & 5 \\
13 & Sulfur & 0,2 & 0,2 & 0,2 & 0,2 \\
\hline
\end{tabular}

dan vulkanisat karet dibuat dengan memvariasikan komposisi CR dan NR pada 95/5 phr, 90/10 phr, 85/15 phr, dan 80/20 phr. Pembuatan kompon karet dengan menerapkan prosedur yang mengacu pada ASTM D 3184-89. Uji karakteristik vulkanisasi dilakukan menggunakan Moving Die Rheometer Alfa 2000 (Alfa Technologies, Akron, USA) sesuai metode standard ASTM D 208417 pada suhu $150{ }^{\circ} \mathrm{C}$ selama 30 menit. Evaluasi sifat mekanik vulkanisat karet dilakukan dengan menguji parameter berikut kekerasan (ASTM D 2240, Frank Durometer), kuat tarik (ASTM D 412, UTM Llyod 2000R), perpanjangan putus (ASTM D 412, UTM Llyod 2000R) pada kondisi sebelum dan setelah pengusangan (ASTM D 57304), pampatan tetap (ASTM D 395, E-Set Tester), serta ketahanan terhadap ozon (ASTM D 1149-07, Ozone Chamber). Vulkanisat karet dibuat dengan mencetak kompon karet pada suhu $150{ }^{\circ} \mathrm{C}$ dengan waktu pencetakan sesuai dengan waktu vulkanisasi optimal yang diperoleh dari hasil pengujian karakteristik vulkanisasi. Nilai perubahan setelah pengusangan dihitung berdasarkan persamaan (1).

Perubahan setelah pengusangan $=$

Nilai sebelum pengusangan - setelah pengusangan $\times 100 \%$

Nilai sebelum pengusangan

\section{HASIL DAN PEMBAHASAN}

Perilaku karakteristik vulkanisasi kompon karet sangat dipengaruhi oleh sistem vulkanisasi yang diterapkan pada formulasi kompon karet tersebut. Pada eksperimen ini, sistem vulkanisasi paduan karet dirancang dengan menerapkan kombinasi antara sistem vulkanisasi sulfur efisien dan sistem vulkanisasi oksida logam. Sistem vulkanisasi sulfur effisien untuk memfasilitasi terbentuknya ikatan silang antara molekul NR. Sedangkan sistem vulkanisasi oksida logam dipakai agar antar molekul CR dapat saling membentuk ikatan silang. Tidak seperti elastomer diena lainnya, CR tidak dapat divulkanisasi menggunakan sistem vulkanisasi sulfur karena hanya memiliki kandungan ikatan tak jenuh $\mathrm{C}=\mathrm{C}$ yang sangat sedikit (Smejda-Krzewicka et al., 2020). Sistem vulkanisasi sulfur effisien yang didominasi oleh ikatan monosulfida dipilih agar dapat mengoptimalkan ketahanan oksidatif termal pada vulkanisasi CR/NR sehingga dapat digunakan dalam pembuatan produk karet tahan gempa yang diaplikasikan di luar ruangan.

Hasil analisis karakteristik vulkanisasi sebagai fungsi dari komposisi paduan CR/NR disajikan pada Gambar 1 dan Gambar 2. Terdapat enam nilai yang dihasilkan dari analisis karakteristik vulkanisasi meliputi modulus torsi maksimal $(\mathrm{MH})$, modulus torsi minimal (ML), selisih modulus torsi (MH-ML), waktu pra vulkanisasi $\left(\mathrm{ts}_{2}\right)$, waktu vulkanisasi optimal $\left(\mathrm{t}_{90}\right)$ dan cure rate index (CRI). Nilai MH menggambarkan kekakuan dan modulus geser kompon karet. Nilai ML dapat digunakan untuk memprediksi viskositas yang berkorelasi dengan kemampuan proses kompon karet, sementara nilai MH-ML mengindikasikan besarnya derajat ikatan silang dalam vulkanisat paduan karet yang terbentuk pada saat proses vulkanisasi berlangsung. Waktu pra vulkanisasi adalah waktu yang diperlukan oleh kompon karet untuk memulai terjadinya reaksi vulkanisasi. 
Waktu vulkanisasi optimal adalah waktu yang diperlukan untuk mencapai $90 \%$ dari reaksi vulkanisasi, sedangkan CRI dapat digunakan sebagai pendekatan untuk memprediksi laju reaksi vulkanisasi (Thongpin et al., 2010; Ngamsurat et al., 2011; Ahmaed et al., 2012; Formela et al., 2015; Joseph et al., 2017).

Dari Gambar 1 terlihat bahwa pada komposisi paduan karet CR/NR sebesar 90/10 phr mampu memberikan nilai MH-ML yang tertinggi yaitu $12,58 \mathrm{~kg}-\mathrm{cm}$. Selanjutnya dengan bertambahnya kandungan NR maka nilai MH-ML cenderung mengalami penurunan. Dengan demikian komposisi paduan CR/NR sebesar 90/10 phr memiliki derajat ikatan silang yang paling besar diantara kompon karet dengan komposisi CR/NR yang lain. Ditinjau dari parameter ML, komposisi paduan CR/NR sebesar 90/10 phr juga terlihat memiliki nilai paling rendah yaitu $1,17 \mathrm{~kg}-\mathrm{cm}$ yang berarti bahwa kompon karet yang tersusun dari 90 phr CR dan 10 phr NR merupakan kompon yang paling mudah diolah. NR cenderung memiliki viskositas yang lebih tinggi daripada CR, akibatnya peningkatan jumlah NR dalam paduan karet menyebabkan naiknya nilai ML. Lebih lanjut, dengan meningkatnya rasio NR terhadap $\mathrm{CR}$ juga menghasilkan nilai $\mathrm{MH}$ yang semakin rendah. Sae-oui et al. (2007a) mengungkapkan bahwa penambahan NR dalam paduan $\mathrm{CR} / \mathrm{NR}$ menurunkan kekakuan kompon karet.

Selanjutnya berdasarkan Gambar 2 dapat diketahui bahwa $t_{2}$ sebanding dengan $t_{90}$, dengan masing-masing nilai $\mathrm{ts}_{2}$ dan $\mathrm{t}_{90}$ tertinggi dicapai pada komposisi paduan karet $\mathrm{CR} / \mathrm{NR}$ sebesar 90/10 phr. Nilai ts ${ }_{2}$ maupun $t_{90}$ cenderung menurun dengan bertambahnya kandungan NR dalam paduan karet yang menyusun kompon karet tersebut. Pada komposisi TMTD/Sulfur yang ditetapkan sama untuk seluruh kondisi, maka reaksi vulkanisasi dapat berlangsung dengan lebih cepat. Hasil ini sesuai dengan nilai CRI paduan kompon karet CR/NR yang semakin tinggi dengan bertambahnya kandungan NR. Berdasarkan hasil analisis karakteristik vulkanisasi yang disajikan pada Gambar 1 dan Gambar 2 dapat diprediksi bahwa vulkanisasi sulfur oleh molekul NR lebih dominan dibandingkan dengan vulkanisasi oksidasi logam oleh molekul CR. Akselerator TMTD yang digunakan merupakan jenis akselerator sekunder yang memiliki efek sangat cepat. Temuan ini sejalan dengan hasil penelitian Smejda-Krzewicka et al (2020). Pada kandungan $\mathrm{CR}$ yang lebih tinggi dalam paduan karet, maka $\mathrm{t}_{90}$ cenderung lebih panjang. Vulkanisasi CR menghasilkan gas klorin sebagai hasil samping. Keberadaan gas klorin ini menghambat reaksi vulkanisasi sulfur (Hayeemasae et al., 2019).

Besarnya derajat ikatan silang antar

MH-ML $\square \mathrm{MH} \backsim \mathrm{ML}$

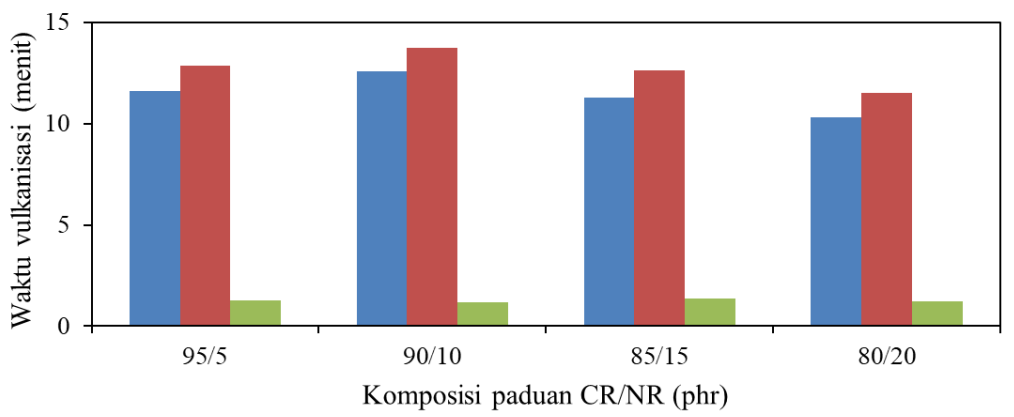

Gambar 1. Modulus torsi kompon karet paduan CR/NR.

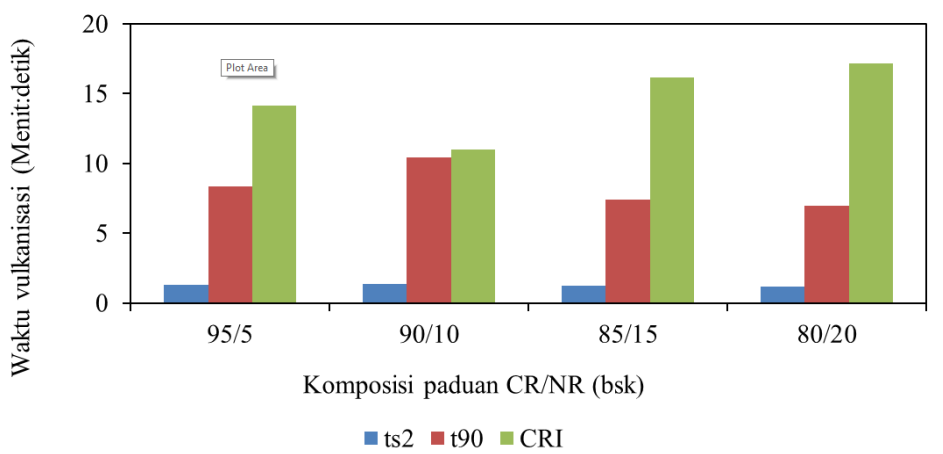

Gambar 2. Waktu vulkanisasi kompon karet paduan CR/NR. 
molekul karet yang terbentuk sebagai akibat dari berlangsungnya reaksi vulkanisasi turut menentukan sifat mekanik vulkanisat karet (Kim et al., 2020). Sifat mekanik vulkanisat karet yang berkorelasi dengan mutu produk karet tahan gempa meliputi kekerasan, elastisitas, ketahanan terhadap pengusangan (retensi) dan ketahanan terhadap ozon. Elastisitas diwakilkan oleh parameter kuat tarik, perpanjangan putus, dan pampatan tetap. Kondisi pengusangan yang dipercepat yang diaplikasikan pada vulkanisat paduan karet $\mathrm{CR} / \mathrm{NR}$ menyebabkan terjadinya perubahan struktur molekul yang diikuti dengan berubahnya sifat mekanik vulkanisat paduan karet CR/NR tersebut (Trong et al., 2020).

Hasil pengukuran kekerasan vulkanisat paduan karet diperlihatkan pada Gambar 3. Dari Gambar 3 tampak bahwa kekerasan vulkanisat paduan karet berada pada kisaran 63-65 Shore A. Meskipun memliki derajat ikatan silang tertinggi, namun vulkanisat paduan CR/NR pada komposisi 90/10 phr justru menghasilkan tingkat kekerasan yang terkecil yaitu 63 Shore. Peningkatan kekerasan dengan bertambahnya kandungan NR dapat disebabkan karena NR memiliki viskositas Mooney yang lebih tinggi dari CR. Karet dengan viskositas Mooney yang tinggi cenderung lebih keras. Hasil ini terkonfirmasi oleh nilai ML pada kandungan NR sebesar 15 dan 20 phr nilai ML yang naik menjadi $1,35 \mathrm{~kg}-\mathrm{cm}$ dan $1,26 \mathrm{~kg}-\mathrm{cm}$ (Gambar 1) dan hasil invensi oleh Sae-oui et al. (2007b). Sementara pada komposisi paduan CR/ NR, tingkat kekerasan tidak berubah. Sementara perubahan nilai kekerasan setelah pengusangan sebesar +3 hingga +5 Shore A. Nilai positif pada perubahan kekerasan setelah pengusangan berarti bahwa vulkanisat paduan karet CR/NR menjadi lebih keras setelah terpapar oleh oksigen pada suhu dan durasi tertentu sesuai kondisi pengujian pengusangan yang dipercepat.
Kuat tarik vulkanisat paduan karet $\mathrm{CR} / \mathrm{NR}$ sebagaimana ditunjukkan pada Gambar 4, tampak cukup tinggi pada kisaran 15,5 hingga 18,1 $\mathrm{MPa}$. Struktur makromolekul baik NR maupun CR dapat mengalami strain induced crystallization pada saat diregangkan, yang menyebabkan kedua jenis karet ini memiliki kuat tarik yang besar (Ismail \& Leong, 2001). Kemampuan kristalisasi NR dan CR diakibatkan karena kedua karet memiliki struktur makromolekul yang sama, hanya gugus metil pada NR digantikan oleh atom $\mathrm{Cl}$ pada struktur molekul CR (Anggaravidya et al., 2020). Dari Gambar 4 juga terlihat bahwa dengan bertambahnya komposisi NR dalam paduan vulkanisat karet $\mathrm{CR} / \mathrm{NR}$, maka diperoleh nilai kuat tarik yang cenderung fluktuatif. Kuat tarik tertinggi sebesar 18,1 MPa dicapai pada komposisi paduan CR/NR sebesar 95/5 phr, sedangkan kuat tarik terendah sebesar $15,5 \mathrm{MPa}$ dihasilkan dari vulkanisat paduan karet CR/NR sebesar 80/20 phr.

Pada kondisi setelah pengusangan, dari Gambar 4 terlihat bahwa hanya vulkanisat paduan karet CR/NR pada komposisi 90/10 phr yang memiliki nilai positif yang berarti terjadi peningkatan kuat tarik setelah vulkanisat paduan karet CR/NR 90/10 phr mengalami pengusangan yang dipercepat. Sebaliknya pada komposisi CR/ NR yang lain, tampak terjadinya penurunan kuat tarik setelah kondisi pengusangan (perubahan kuat tarik bernilai negatif). Peningkatan kuat tarik setelah pengusangan dapat disebabkan karena terjadinya reaksi lanjut pembentukan ikatan silang antar molekul CR maupun NR. Sebaliknya penurunan kuat tarik dapat diakibatkan karena terjadinya pemutusan ikatan silang antar molekul CR maupun NR. Perubahan nilai kuat tarik setelah pengusangan terkecil $(+2,4 \%)$ ditunjukkan oleh vulkanisat paduan karet CR/NR sebesar 90/10 phr. Dengan perubahan kuat tarik yang kecil bahkan bernilai positif, maka vulkanisat paduan $\mathrm{CR} / \mathrm{NR}$

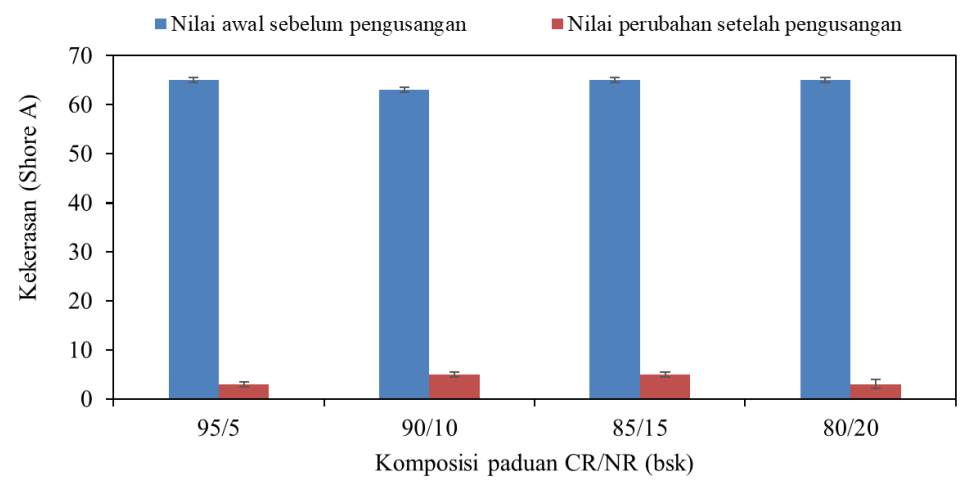

Gambar 3. Nilai kekerasan vulkanisat paduan karet CR/NR. 
90/10 phr dianggap memiliki ketahanan terhadap oksidatif termal yang baik.

Gambar 5 menyajikan hasil pengukuran perpanjangan putus vulkanisat paduan karet $\mathrm{CR} /$ NR. Penurunan nilai perpanjangan putus sebesar $10 \%$ terjadi pada peningkatan kandungan NR dari $5 \mathrm{phr}$ menjadi $10 \mathrm{phr}$, kemudian pada penambahan kandungan NR selanjutnya sebesar $15 \mathrm{phr}$ dan $10 \mathrm{phr}$ tidak terjadi perubahan nilai perpanjangan putus $(410 \%)$. Penambahan komponen NR dalam paduan karet CR/NR tidak berdampak besar terhadap sifat perpanjangan putus yang dihasilkan oleh vulkanisat paduan karet tersebut baik pada kondisi sebelum maupun setelah pengusangan. Terlihat dari Gambar 5, bahwa vulkanisat paduan CR/NR sebesar 85/15 phr dan 80/20 phr memiliki nilai perpanjangn putus yang sama baik sebelum pengusangan $(410 \%)$ maupun perubahan nilai setelah pengusangan $(-9,7 \%)$. Sementara itu kecenderungan yang sama juga diperlihatkan oleh vulkanisat paduan CR/NR 90/10 phr. Paduan karet tersebut menghasilkan nilai perubahan perpanjangan putus paling rendah dibandingkan dengan komposisi karet yang lain sebagaimana terjadi pada kuat tarik.

Pampatan tetap adalah menggambarkan kemampuan vulkanisat karet kembali ke bentuk semula setelah mengalami deformasi akibat dikenai tekanan. Nilai pampatan tetap vulkanisat paduan karet CR/NR ditampilkan pada Gambar 6. Dari Gambar 6 tampak bahwa pampatan tetap paling rendah dihasilkan dari vulkanisat paduan karet CR/NR sebesar 90/10 phr. Pampatan tetap berbanding terbalik dengan nilai derajat ikatan silang. Vulkanisat paduan karet dengan derajat ikatan silang yang tinggi, akan menghasilkan nilai pampatan tetap yang rendah. Vulkanisat paduan karet dengan nilai pampatan tetap rendah akan memiliki kemampuan menahan deformasi akibat penekanan yang baik.

- Nilai perubahan setelah pengusangan

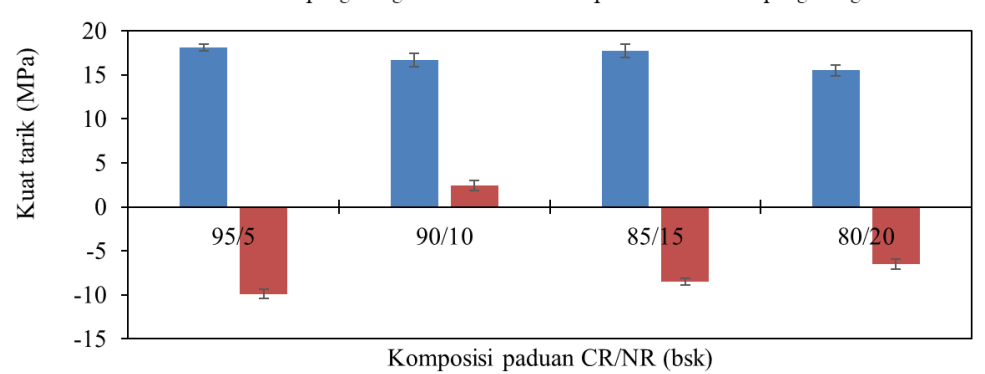

Gambar 4. Nilai kuat tarik vulkanisat paduan karet CR/NR.

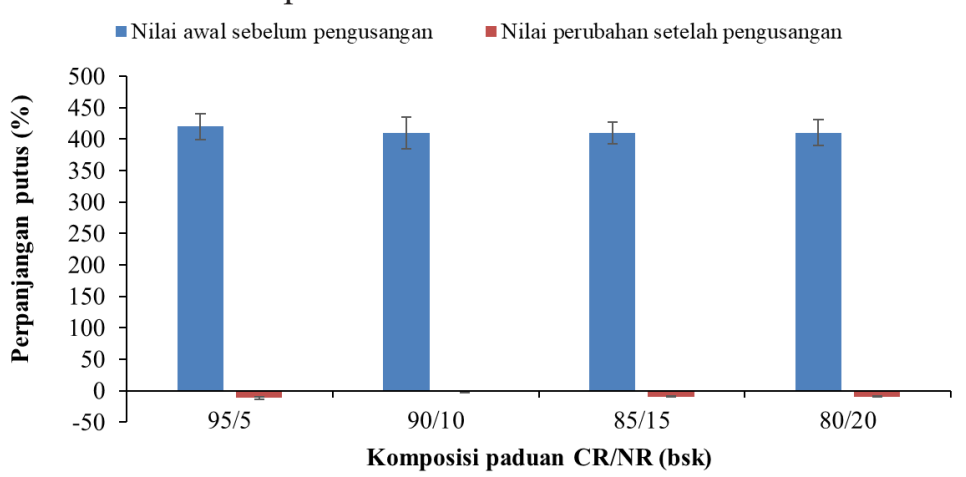

Gambar 5. Nilai perpanjangan putus vulkanisat paduan karet CR/NR.

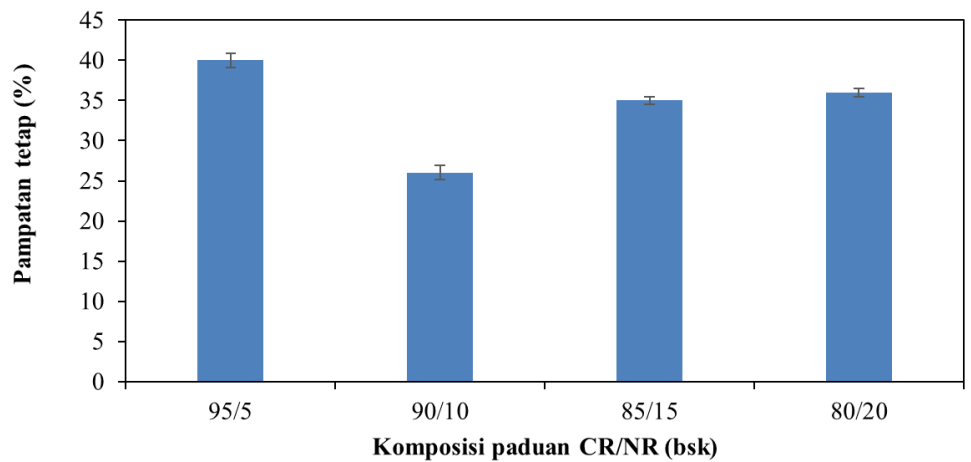

Gambar 6. Nilai pampatan tetap vulkanisat paduan karet CR/NR. 
Pengujian ketahanan ozon yang dilaksanakan pada kondisi konsentrasi ozon 100 pphm selama 100 jam pada seluruh vulkanisat paduan karet CR/ NR menunjukkan bahwa tidak tampak adanya retakan (crack) pada permukaan vulkanisat paduan karet pada seluruh komposisi. Dengan demikian, penambahan NR sebesar $20 \mathrm{phr}$ dan dengan menerapkan sistem vulkanisasi sulfur effisien masih mampu menangkal serangan ozon sebagaimana yang dipersyaratkan pada produk karet tahan gempa.

\section{KESIMPULAN}

Teknik mengkombinasikan dua atau lebih jenis karet yang berbeda telah banyak diterapkan oleh para peneliti maupun perancang kompon karet saat menyusun formulasi kompon karet. Dengan memadukan karet sintetik tipe kloroprena (CR) dan karet alam (NR) diharapkan dapat diperoleh komposisi base elastomer yang sesuai digunakan sebagai matriks pada komposit material karet penyusun produk karet tahan gempa. Berdasarkan hasil eksperimen diketahui bahwa komposisi terbaik paduan CR/NR adalah pada 90/10 phr. Paduan karet tersebut berpotensi untuk dikembangkan menjadi produk karet tahan gempa karena dapat menghasilkan kompon yang mudah diproses (ML 1,17 kg-cm), derajat ikatan silang yang tinggi (MH-ML 12,58 kg-cm) dan diikuti dengan sifat mekanik dan termal yang unggul, diantaranya kekerasan (63 Shore A), kuat tarik (16,7 MPa), perpanjangan putus $(410 \%)$, dan pampatan tetap (26\%), tahan terhadap serangan ozon pada konsentrasi ozon sebesar $100 \mathrm{pphm}$ selama $100 \mathrm{jam}$, perubahan setelah pengusangan yang rendah pada parameter kekerasan $(+5)$, kuat tarik $(+2,4 \%)$, dan perpanjangan putus $(-2,4 \%)$. Sifat mekanik komposit CR/NR sebesar 90/10 phr tersebut juga memenuhi persyaratan High Damping Rubber Bearing (HDRB, kisaran modulus geser 1,1 - 1,5 MPa) yang ditetapkan dalam EN 15129.

\section{UCAPAN TERIMA KASIH}

Penulis menyampaikan terima kasih dan memberikan penghargaan kepada Lembaga Pengelola Dana Pendidikan/Kementerian Keuangan dan Kementerian Ristek/Badan Riset Nasional atas bantuan pendaanan melalui Insentif Program Prioritas Riset Nasional (PRN) Tahun 2020/2021 dengan Kontrak Riset Nomor 152/E1/ PRN/2020. Ucapan terima kasih turut disampaikan kepada seluruh Teknisi Pabrik Percobaan dan Analisis Laboratorium Penguji Balai Penelitian Teknologi Karet.

\section{DAFTAR ISI}

Ahmed, K., Nizami, S. S., Raza, N. Z., \& Shirin, K. (2012). Cure characteristic, mechanical, and swelling properties of marble sludge filled EPDM modified chloroprene rubber blends. Advanced in Material Physics and Chemistry, 2, 90-97. https://doi.org/10.4236/ampc.2012.22016

Anggaravidya, M., Amry, A., Arti, D. K., Kalembang, E., Susanto, H., Hidayat, A. S., \& Limansubroto, C. D. (2020). Properties of natural rubber/chloroprene rubber blend for rubber fnder application: Effects of blend ratio. Macromolecular Symposia, 391(1), 1900150. https://doi.org/10.1002/masy.201900150

Ferraioli, M., \& Mandara, A. (2016). Base isolation for seismic retrofitting of a multiple building structure: Evaluation of equivalent linearization method. Mathematical Problems in Engineering, 2016, 8934196. https://doi.org/10.1155/2016/8934196

Formela, K., Wasowicz, D., Formela, M., Hejna, A., \& Haponiuk, J. (2015). Curing characteristic, mechanical and thermal properties of reclaimed ground tire rubber cured with various vulcanization systems. Iranian Polymer Journal, 24, 289-297. https://doi.org/10.1007/s13726-015-0320-9

Galiani, P. D., Malmonge, J. A., Soares, B. G., \& Mattoso, L. H. C. (2013). Studies on thermal oxidative degradation behaviours of raw natural rubber: PRI and themogravimetry analysis. Plastics, Rubber and Composites, 42(8), 334-339. https://doi.org/10.1179/174328981 1 Y.0000000046

Hayeemasae, N., Salleh, S. Z., \& Ismail, H. (2019). Sustainable use of chloroprene rubber waste as blend component with natural rubber, epoxidized natural rubber and styrene butadiene rubber. Journal of Polymers and the Environment, 27, 2119-2130. https://doi.org/10.1007/s10924-01901503-1

Ismail, H., \& Leong, H. C. (2001). Curing characteristics and mechanical properties of natural rubber/ chloroprene rubber and epoxidized natural rubber/ chloroprene rubber blends. Polymer Testing, 20, 509-516. https://doi.org/10.1016/S01429418(00)00067-2

Joseph, A. M., George, B., Madhusoodanan, K. N., \& Alex, R. (2017). Cure characteristic of devulcanized rubber: The issue of low scorch. Rubber Chemistry and Technology, 90(3), 536-549. https://doi.org/10.5254/rct.17.83737

Kim, D. Y., Park, J. W., Lee, D. Y., \& Seo, K. H. (2020). Correlation between the crosslink characteristic and mechanical propertis of natural rubber 
compound via accelerators and reinforcement. Polymers, 12, 14p. https://doi.org/10.3390/ polym 12092020

Ngamsurat, S., Boonkerd, K., Leela-adisorn, U., \& Potiyaraj, P. (2011). Curing characteristics of natural rubber filled with gypsum. Energy Procedia, 9, 452-458. https://doi.org/10.1016/j. egypro.2011.09.051

Nishi, T., Suzuki, S., Aoki, M., Sawada, T., \& Fukuda, S. (2019). International investigation of shear displacement capacity of various elastomeric seismic-protection isolators for buildings. Journal of Rubber Research, 22, 33-41. https://doi. org/10.1007/s42464-019-00006-x

Olejnik, A., Smejda-Krzewicka, A., \& Strzelec, K. (2019). Effect of antioxidants on aging of the chloroprene rubber/butadiene rubber (CR/BR) blends. International Journal of Polymer Analysis and Characterization, 24(6), 475-486. https://doi. org/10.1080/1023666X.2019.1602922

Ramallo, J. C., Johson, E. A., \& Spencer, B. F. (2002). Smart base isolation systems. Journal of Engineering Mechanics, 128(10), 1088$1099 . \quad$ https://doi.org/10.1061/(ASCE)07339399(2002)128:10(1088)

Sae-oui, P., Sirisinha, C., Wantana, T., \& Hatthapanit, K. (2007a). Influence of silica loading on the mechanical properties and resistance to oil and thermal aging of CR/NR blends. Journal of Applied Polymer Science, 104, 3478-3483. https://doi.org/10.1002/app.26139

Sae-oui, P., Sirisinha, C., \& Hatthapanit, K. (2007b). Effect of blend ratio on aging, oil and ozone resistance of silica-filled chloroprene rubber/ natural rubber (CR/NR) blends. Express Polymer Letter, 1(1), 8-14. $\quad$ https://doi.org/10.3144/ expresspolymlett.2007.3

Smejda-Krzewicka, A., Olejnik, A., \& Strzelec, K.
(2019). The role of iron (III) oxide in chloroprene and butadiene rubber blends cross-linking, structure, thermal and mechanical characteristic. Iranian Polymer Journal, 28, 313-323. https:// doi.org/10.1007/s13726-019-00701-x

Smejda-Krzewicka, A., Olejnik, A., \& Strzelec, K. (2020a). The effect of metal oxide on the cure, morphology, thermal and mechanical characteristics of chloroprene and butadiene rubber blends. Polymer Bulletin, 77, 4131-4146. https://doi.org/10.1007/s00289-019-02964-z

Smejda-Krzewicka, A., Slubik, A., Strzelec, K., \& Rybinski, P. (2020b). Study on the effect of zinc on the rheological, mechanical, and thermal properties and fire hazard of unfilled and filled CR/BR vulcanizates. Polymers, 12, 20p. https:// doi.org/10.3390/polym12122904

Thongpin, C., Niltui, P., Sornwaneenawakhun, P., Maneeprom, T., Malithong, S., \& Wimolmala, E. (2010). Cure characteristic and mechanical properties of epoxidized natural rubber/ chloroprene (ENR/CR) blends. Advanced Material Research, 93-94, 631-634. https://doi. org/10.4028/www.scientific.net/AMR.93-94.631

Trong, Q. N., Viet, H. D., Duy, L. N. P., Bui, C., \& La, D. D. (2020). Detailed study on the mechanical properties and activation energy of natural rubber/chloroprene rubber blends during aging processes. Journal of Chemistry, 2020, 7p. https:// doi.org/10.1155/2020/7064934

Verma, A., Gupta, A., \& Nath, B. (2017). Base isolation system: A review. Internasional Journal of Engineering Science Invention, 6(9), 43-46.

Warn, G. P., \& Ryan, K. L. (2012). A review of seismic isolation for buildings: Historical development and research needs. Buildings, 2, 300-325. https:// doi.org/10.3390/buildings2030300 